\title{
Board of Directors and the Limits of the Conflict of Interest Definition within Codes of Ethics
}

\author{
Emiliano Di Carlo ${ }^{1}$ \\ ${ }^{1}$ Department of Management and Law, University of Rome "Tor Vergata", Italy \\ Email: dicarloe@uniroma2.it
}

\begin{abstract}
According to agency theory the main role of the board of directors (BoD) is to recognize and monitor the conflict of interest (CoI) between managers and shareholders or between the majority shareholder and minority shareholders. This monitoring role requires that board members are able to identify CoI situations. In this the code of ethics and code of conduct are regarded guides for directors, since these codes often contain the CoI policy of the firm. The objective of this study is to understand if a CoI definition is sufficient to identify CoI situations. The results of a questionnaire administrated to 18 directors who sit in the boards of several subsidiaries of an Italian listed group show that directors sometimes fail in recognising CoI situations. Thus in order to increase the effectiveness of the board, companies should provide examples to facilitate its identification and resolution.
\end{abstract}

Keywords: Board of directors, code of conduct, code of ethics, conflict of interest, corruption, opportunistic behaviour.

\section{Introduction}

In terms of agency theory the main role of the board of directors is to monitor the conflict of interest (CoI) between managers and shareholders (Berle and Means 1932; Eisenhardt 1989; Fama 1980; Fama and Jensen 1983; Fields and Keys 2003; Jensen and Meckling 1976) and between majority shareholder and minority shareholders in a firm (Claessens et al. 2000; Morck and Yeung 2003; Shleifer and Vishny 1997). Indeed, the board of directors is considered as one of the internal governance mechanisms together with concentrated ownership and executive compensation packages (Demsetz and Lehn, 1985; Fama and Jensen, 1983).

This monitoring role requires that directors are able to recognise CoI situations, even their own CoI. In this the code of ethics and code of conduct are regarded guides for directors (Felo, 2001), since these codes often contain the CoI policy of the firm. Previous researches document the presence of a CoI statement within codes of ethics (Brooks 1989; Carasco and Singh 2003; Cressey and Moore 1983; Di Carlo and Testarmata 2011 and 2012; Hite et al. 1988; Lefebvre and Singh 1992; Gaumnitz and Lere 2002; Kaptein 2004; Singh 2006; White and Montgomery 1980). For example, Cressey and Moore (1983) examine the contents of 119 codes of American corporations with three dimensions, including policy (specific issues addressed in the code), authority (what makes the codes policies ethical, morally necessary or legitimate) and compliance procedures. The conflict of interest was the most emphasized item in the policy area. Hite et al. (1988) content analyse 67 codes of Fortune 500 corporations, founding that the conflict of interest is one of the most frequently covered issues. Similar results exist in the study of Lefebvre and Singh (1992) which use content analysis for the codes of 75 of Canadian top 500 companies. Di Carlo and Testarmata (2011) focus on CoI section of codes of ethics issued by 57 Italian listed companies and find that $52 \%$ of those codes ask to resolve the CoI (e.g. through recusal and disclosure) without defining what $\mathrm{CoI}$ is.

Scholars who have dealt with the CoI definition (Carson 1994; Davis 1982, 1993; Davis \& Stark, 2001; Resnik 1998; Thompson 2009) highlight the difficulties encountered for the identification of the phenomenon, despite the presence of this definition. For this reason, they often support their CoI definition providing various examples in order to facilitate the CoI identification (Carson 1994; Davis 1993). In this respect, the code of ethics is fundamental, since it could provide both a CoI definition as well as concrete examples that facilitate its recognition (Di Carlo and Testarmata 2011). 
Even if the code of ethics is adopted by the firm it does not mean that the addresses know or completely understand its contents, so it was stressed the need to find appropriate means of code implementation (Schwartz 2004).

A study conducted by Di Carlo (2013) on the knowledge of CoI by the Italian civil servants showed that despite the presence of a code of ethics, where asked to deal with the CoI, the way in which they identify the CoI is not homogeneous. These differences could be caused by the following factors: 1) respondents do not know the contents of the codes of ethics so they use their own knowledge to identify the phenomenon; 2) even knowing the contents they appear inadequate for the CoI identification.

The objective of this study is to understand if a CoI definition is sufficient to identify CoI situations, assuming that individuals are fully aware of that definition. In order to achieve this objective, a questionnaire was administrated as part of a training course on 'Conflict of interest and corruption' to the subsidiary boards of a multinational group with a holding company listed on the Italian Stock Exchange. In answering the questionnaire they have a possibility to learn the CoI definition contained in their code.

Our findings indicate that: (1) the CoI recognition is not an easy task; (2) directors sometimes fail in recognising their own CoI, thus they do not activate remedies provided to deal with it; (3) the CoI is often confused with other forms of conflicts (e.g. conflict of commitment); (4) some directors give to the CoI an extremely negative connotation considering it as a form of corruption (i.e., an opportunistic behaviour); (5) some form of corruption (e.g., cronyism and nepotism) are not considered as corruption, while some others (e.g. the capture) are not known.

The reminder of this paper is organised as follows. The next section presents the theoretical framework. Section 3 focuses on the concept of CoI, differentiating the actual CoI from the potential and apparent ones. Section 4 distinguishes the CoI from the opportunistic behaviour, while Section 5 discusses CoI from conflict of commitment and the competing interests. The methods are presented in the Section 6. The results from the questionnaire and the main findings are subsequently discussed in Section 7. The last section summarises the basic results, addresses the potential implications for researchers, practitioners and regulators, and discusses the limitations of the study.

\section{Theoretical Framework}

Agency theory was established on an essential argument on the conflict of interest. Indeed that theory focuses on the agency problem type I and II. The former is connected to the CoI that characterizes the relationship between managers and shareholders (Berle and Means 1932; Eisenhardt 1989; Fama 1980; Fama and Jensen 1983; Jensen and Meckling 1976) while the latter on the CoI between majority shareholder and minority shareholders (Claessens et al. 2000; Morck and Yeung 2003; Shan 2013; Shleifer and Vishny 1997; Young et al. 2008).

However, scholars seem to underestimate the need to deeply define what CoI is, for example, what kind of private interests may cause CoI situations, as well as in which way they may conflict or interfere with the interest of the shareholders, stakeholders or firm.

It may depend on three main reasons: (1) CoI does not need to be defined, because of the assumption that the meaning is already well known, indeed often codes of ethics do not define the CoI even if these codes ask to deal with it (Di Carlo 2013); (2) the idea that is more useful to characterise something by explaining the range of meanings ascribed either explicitly or implicitly, but with the risk that two directors of the same company interpret the same situation in different way (Friedman 1992), for instance, one sees the conflict while the other does not; (3) the wrong assumption that the concept of CoI is just the other side of the coin of independence, and the concept of directors' independence has received much attention from corporate governance scholars (Kaplan and Reishus 1990; Mace 1971; Morck 2008).

Moreover, corporate governance studies as well as the codes of best practice seem not to resolve many important issues, such as the differences between potential, apparent, and actual CoI, even if the terms potential and apparent are often recalled by these codes (Di Carlo and Testarmata 2011).

Thus, in recognizing and managing directors' CoI it is extremely important to distinguish and clearly define the three different types of directors' CoI: actual, potential and apparent CoI (Davis, 1993; Resnik, 1998). Indeed each type of conflict requires specific remedies to deal with it. 
The discussion will follow the framework presented in Figure 1 that contains the elements that characterise the $\mathrm{CoI}$ as well as those that allow distinguishing the $\mathrm{CoI}$ from corruption, conflict of commitment and competing interests. That distinction is important considering that the term CoI can be confused with these other terms (Resnik 1998; Werhane and Doering 1997).

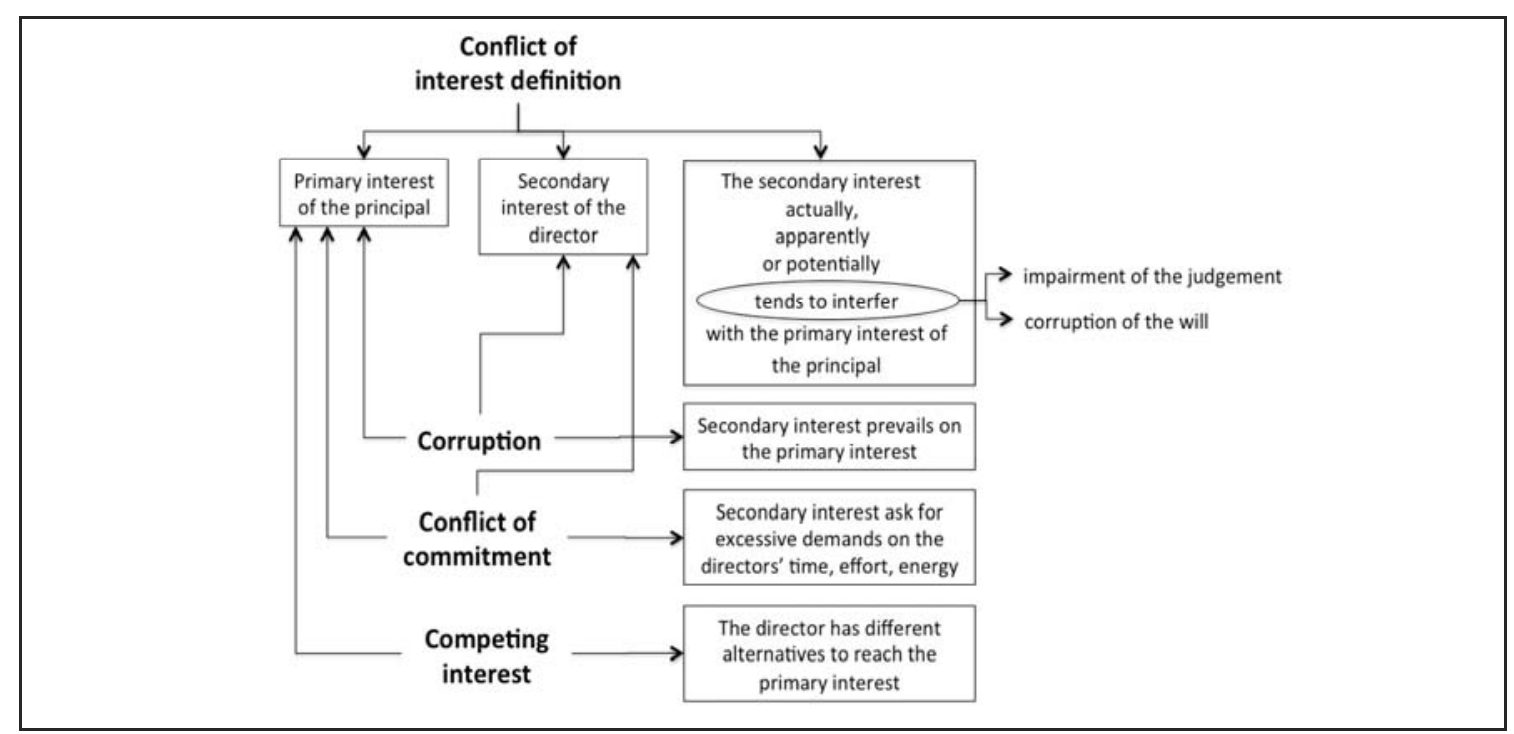

Figure 1. Conceptual framework (Source: author elaboration)

\section{Defining Actual, Apparent and Potential Conflict of Interest}

\subsection{Actual Conflict of Interest}

The actual (or real) conflict of interest is the situation where a director has a secondary interest tending to interfere with the interest of the principal. The CoI is regarded as 'actual' when it occurs during the decision-making process of the director. Thus, when the director is required to act independently, without interference, the secondary interest tends to interfere.

The definition contains the following three key elements (Figure 1):

- primary interest of the principal;

- secondary interest of the director;

- the secondary interest of the director tends to interfere with the primary interest of the principal.

\subsubsection{The Primary Interest}

The 'primary interest' of the director is referred to the duty that he/she has in reaching the interest of the principal. The term for the principal is normally referred to the shareholders, stakeholders or firm (Di Carlo and Testarmata 2011).

The shareholder approach derives from the shareholder theory, for which the agents (managers) have a moral obligation to maximise the value of the principals (the shareholders) (Friedman, 1970). The firm is seen as a legal fiction, an instrument owned by the shareholders to maximise their profit. In this theory, the interest of the firm coincides with that of shareholders. Thus, when codes of ethics and scholars refer to the conflict of interest with the firm (Carasco and Singh 2003; Orts 2001; Schwartz et al. 2005) it may coincide with the conflict of interest with the shareholders or the firm.

The most recent stakeholder theory draws attention to the need to balance the value creation for shareholder with the protection of the interests of the stakeholders (Freeman, 1984). This theory recognises that there is an ethical dimension, in addition to economic and legal ones, as well as a moral duty for those who govern the company to consider the rights of all those involved (Donaldson and Preston, 1995). The stakeholder theory is born with the idea of overcoming a personal finalism and proposes a wider finalism, which must be translated into ethical principles of managerial behaviour. 
Some scholars, mainly in the field of company law (Keay 2008; Ireland 1999; Stout 2013), consider the firm as a separate institution from all its stakeholders. This approach is followed by the organic theory and social entity theory (Lan and Heracleous, 2010). According to that idea a situation can be in CoI with the firm but in line with the interest of the shareholders. It could be the case when the management has an interest in manipulating the financial statements to increase the market value of the company and thus his/her compensation. The manipulation could satisfy both the interest of the management and that of the short-term shareholders, causing damage to the firm and the other stakeholders in the long-term (e.g. Enron).

\subsubsection{The Secondary Interest}

The 'secondary interest' is typically a financial gain and could be seen as an extrinsic motivation. Individuals are 'extrinsically motivated if they are able to satisfy their needs indirectly, especially through monetary compensation' (Osterloh and Frey 2000, p. 539). Financial conflicts are may be the easiest to identify, but they may not be the most influential. The agent can also have non-financial (personal) interests (Thompson 2009). Indeed, secondary interest may also include desire for professional advancement, recognition for personal achievement, and favour to friends and family (Foster 2003). Referring to the board members, Orts (2001, p. 129) points out that the private interest can conflict with firm interests in two related ways: financial and personal. The CoI that arises from divergent financial interests includes three common situations: (1) salary and compensation, (2) taking corporate business opportunities, and (3) mergers, acquisitions, and the sale of corporate control.

Furthermore, while for some scholars the private interest must have a tangible value for the agent (Boatright 1992) for others the private interest can also include a desire without tangible value (Carson 1994; Davis 1982). For example, for the former if the director is tempted to hire the candidate who supports his/her football team, this desire to promote the interest of that party does not generate a CoI, due to the lack of tangible private interest for the former. In this regard, Borden and Pritchard (2001) point out that 'not every factor that might interfere with one's judgment creates a conflict of interest [...] What is necessary for a conflict of interest is another interest, the presence of which inherently threatens to interfere with the independent exercise of judgment' (p. 80).

It does not mean that the desires without tangible private interests are not able to influence the agent behaviour. However, this potential distortion should be controlled through the compliance with the duty of impartiality (or non-discrimination), not through the CoI policy. In code of ethics impartiality is considered as core moral value (Schwartz 2005).

\subsubsection{The Tendency to Interfere}

There are different terms used by scholars and code of ethics to describe what happens to the primary interest when the agent has a secondary interest (Di Carlo and Testarmata 2012) (i.e. the secondary interest: interfere; influence; conflict; undermine; contrast, etc.).

In the proposed definition (third element of the CoI definition) the author uses the term tends to interfere' (Figure 1) suggested by Resnik (1998) and Davis (1982) in order to emphasize that the interference of the secondary interest occurs with varying intensity depending, among the other things, on the value of the director's secondary interest and the importance assumed by that interest. Resnik (1998) argues 'tendencies admit of degrees [...] When it comes to conflicts of interest, some situations tend to undermine our judgment or will more than others' (p. 392). It is not adequately considered that the CoI may have different degrees of severity (Thompson, 2009), depending on the likelihood of undue influence and of the seriousness of harm or wrong.

According to Resnik (1998) definition of CoI, focusing on director's decision-making, the secondary interest tends to interfere in two ways: 1) with the proper exercise of judgment (impairment of the judgment); 2) with the director's ability to fulfill his/her fiduciary duty (corruption of the will). Both of these cases can have adverse impact on directors' objectivity and trustworthiness.

According to Davis (1982), judgment is a form of cognitive activity, such as decision-making, observation and evaluation. The judgment requires more than mechanical rule-following or common sense. The CoI tends to impair the judgment, and can lead to make unsound decisions, observations and evaluations.

The judgment could be impaired in two ways by the CoI (Davis 1982; Resnik 1998). First, the CoI may bias a judgment. A director who is asked to assess a manager who is also his/her relative is likely to make a biased assessment. People who know this bias can compensate for it. Using the Resnik's example, it can be said that this situation is likely when one has a thermometer consistently 
underestimates air temperature by two degrees centigrade then he/she can correct this bias by making adjustments in the temperature recorded (Resnik 1998). Second, a CoI may render a director's judgment unreliable. A director with biased judgment makes errors that are slanted or skewed in a particular way. In this case, the director's judgment is like a broken thermometer that in some situations overestimates temperature, in others underestimates it. For example, in the previous situation one might expect the director will give a positive evaluation on the manager since the familiar link (biased judgement). But the director might try to compensate for his impairment and make too many critical observations against his relative, and these observations are likely to be unreliable.

Moving to corruption of the will, Resnik (1998) observes that 'the will is that part of the person that transforms cognitive states into actions' (p. 389). Many situations of director's CoI involve corruption of the will instead of impairment of the judgment. Differently from bias of the judgment, in corruption of the will director may know how to carry out his/her duties, but he/she tends to fail to do so because he/she ignores these duties in order to satisfy his/her private interest. For example, a director may fail to comply with the procedure provided by the firm to approve a transaction with a party that is related to the director.

\subsection{Apparent Conflict of Interest}

The apparent (or perceived) conflict of interest is the situation where a director has a secondary interest that appears to outside observer(s) to interfere with the interest of the firm (Figure 1).

Indeed, an apparent CoI exists when a reasonably well-informed outside observer could have a reasonable apprehension that the secondary interest interferes with the primary interest of the principal (Davis, 1993; OECD, 2005; Resnik, 1998). Outside observers may include, for example, other board members, shareholders, the press, and members of the public.

All CoIs involve perceptions or appearances because they are specified from the perspective of people who do not have sufficient information for assessing the actual motives of a decision maker and the effects of those motives on the decisions themselves (Lo and Field 2009).

Simply the presence of a secondary interest is enough to say that an apparent CoI exists, since the outside observers cannot evaluate the interference of the secondary interest on the primary one.

Thus, the need to deal with CoI of the agents is based on two propositions: 1) they must avoid situations in which private interests can affect their duties; 2) situations where there is the appearance of a CoI must also be avoided, if only because protestations of innocence and integrity may be impossible to judge.

In U.S., the apparent association between corporate fraud (e.g. Enron and WorldCom) and relatedparty transactions (RPTs) leads the Sarbanes-Oxley Act of 2002 (Section 402) to prohibit listed companies from extending, arranging or renewing personal loans to or for their directors and executive officers (Gordon et al., 2004). The tendency of firms might be to prohibit or to hide RPTs, reporting them as transactions with unrelated parties (Gordon et al. 2004, 2007; Kohlbeck and Mayhew, 2010), when the benefit deriving from their conclusion or disclosure could be outweighed by costs associated with the decrease of share market value, even if the RPTs are not engaged for expropriation purposes, instead they are concluded in the interest of the firm and their outsiders. RPTs can generate an apparent $\mathrm{CoI}$ and at the same time they can be beneficial to the firm.

Agency theorists have proposed internal and external governance mechanism (e.g. board of directors, ownership structure, market for corporate control, legal environment) a long time ago to prevent or resolve the apparent and actual CoI (Gillan, 2006).

\subsection{Potential Conflict of Interest}

The potential $\mathrm{CoI}$ is the situation where a director has a secondary interest that could interfere in the future with the interest of the principal. For example, directors who have family and/or professional relationships with the management or the main shareholder are in potential CoI, as well as directors who have financial interest in customers (i.e., director has a partial ownership in a company that buys goods from the firm) or supplier of the firm, since these ties could bring an actual CoI in the future. These parties are all related to the directors. 
A way to manage such potential $\mathrm{CoI}$ is to ask directors and managers to disclose these related parties, in order to choose, for example in case of future transactions with them, the best instruments to deal with (e.g. prohibition and/or recusal). In this regards, in Italy the Italian Security Exchange Commission (Consob) has introduced a Regulation (No. 17221/2010) containing important innovations in this area, which requires a disclosure of any potential conflict of interest.

The difference between apparent and potential $\mathrm{CoI}$ is that in the former the self-interest (second element of the CoI definition shown in Figure 1) may be just apparent, whereas in the latter the selfinterest exists, consequently the potential conflict could turn into a real conflict in the future.

\subsubsection{Potential Conflict of Interest in Agency Theory}

In agency theory the potential conflict of interest stems from the fact that the holders of the residual claims on the firm, the owners (principals), are different from managers (agents) that exercise the rights of control of the company (Berle and Means 1932; Eisenhardt 1989; Fama 1980; Fama and Jensen 1983; Jensen and Meckling 1976). Therefore, the interests of managers are not naturally aligned with that of the shareholders, since the former are considered as opportunistic and self-serving. However, the concept of the private interest of the agent is not perfectly comparable to the concept of secondary interest used in the proposed CoI definition (Section 3.1).

The difference mainly lies on the fact that the private interest of the agency theory is potential and derives from the separation between the ownership and control and from the homo economicus assumption (self-interested), while the secondary interest of the proposed definition is specific and clearly identifiable, since it refers to actual private interests.

Regarding this issue, Baysinger and Hoskisson (1990) state that 'agency theory suggests that this socalled separation of ownership and control is economically efficient, despite the noted potential for conflicts of interest' (p. 75).

As theorized by the agency theory, the private interest of the manager would be to take advantage of future situations with the company putting him/her in concrete situations of potential and actual CoI. However, it is the specific situation that puts the manager in a potential, actual or apparent CoI as previously specified. Therefore, the CEO of a company is seen by the agency theory as a person who will try to put himself/herself in situations that can allow the extraction of private benefits. In that sense according to the agency theory the CEO is in potential CoI. To solve this potential CoI agency theory suggests implementing corporate governance mechanisms including both internal (board of directors, managerial incentives, capital structure) and external governance (market for corporate control, regulation) mechanisms (Denis and McConnell, 2003; Gillan, 2006).

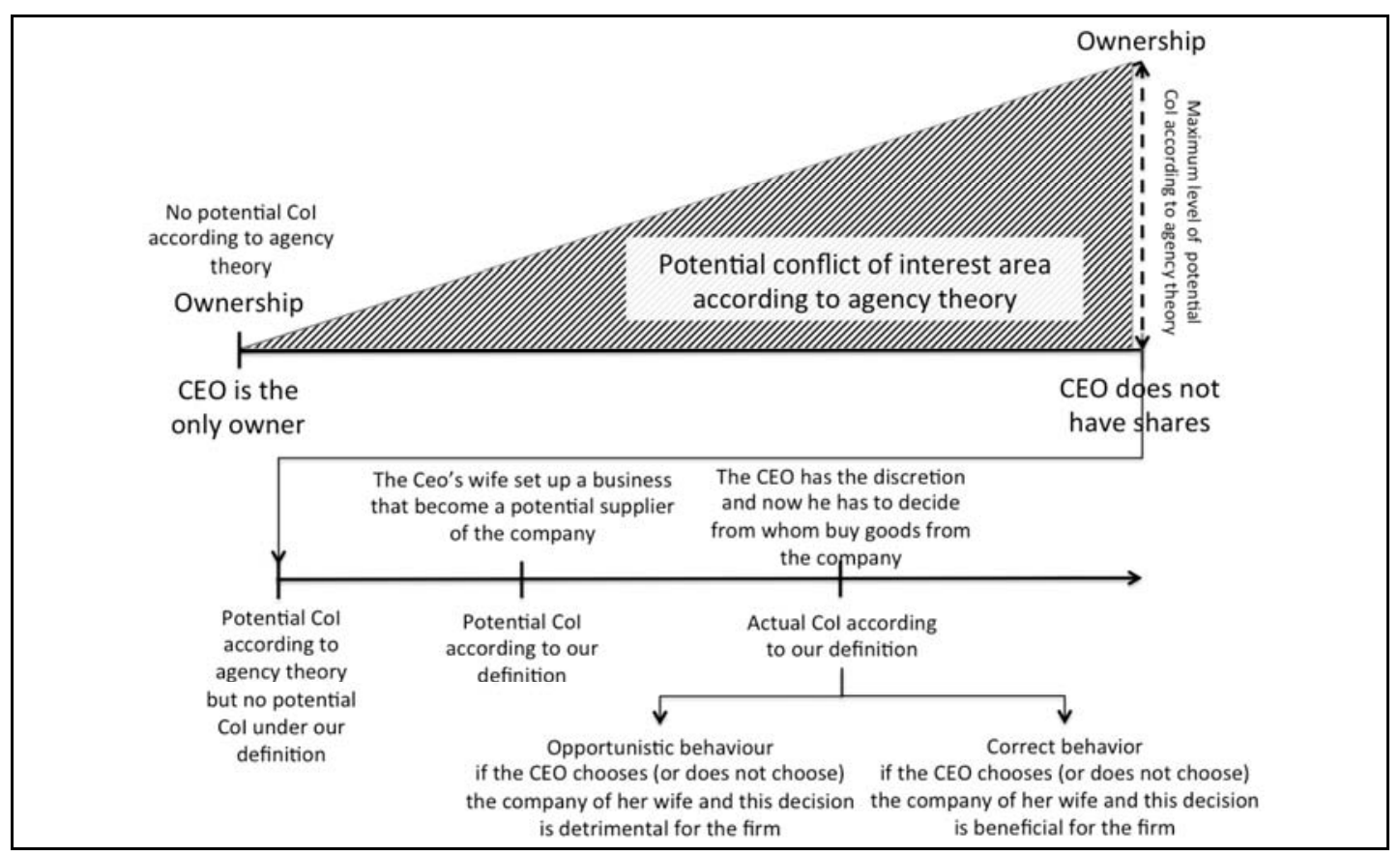


Figure 2. Potential CoI in accordance with agency theory and with the proposed definition

However, according to the proposed definition (Section 3.2) the CEO will be in a concrete situation of potential CoI if, for instance, his wife, as related party, sets up a business that becomes a potential supplier of the company (Figure 2). Thus it is important that the CEO discloses the situation of risk (i.e. the related-party) even if the company does not have yet relationships with his wife's company. This potential CoI will become an actual CoI when the CEO has the discretion to decide from whom to purchase goods for the company. Also this situation must be disclosed giving the possibility to the directors to exercise their monitoring role activating the CoI policies (e.g. recusal of the CEO from the decision-making process, prohibition of the transaction). If the transaction is detrimental to the firm it means that the actual $\mathrm{CoI}$ has been transformed into an opportunistic behaviour. Even if the transaction is beneficial for the company (as well as for the CEO), the CoI, at least the apparent one, persist for the outside observers. The full disclosure of the way the firm managed that conflict may reduce the perceived CoI. The related party transaction policies and procedures are fundamental in this contest, since they ensure the fairness and transparency of transactions. For instance, the firm can mitigate the appearance of $\mathrm{CoI}$ having a procedure that forbid the $\mathrm{CEO}$ to decide a transaction that involve his/her related party.

Moreover, differently from our definition of potential CoI, it seems that for agency theory the term 'potential CoI' is used as a synonymous of 'potential opportunistic behaviour'. This element is not trivial, given that managing the behaviour of a potential harm is different from managing a situation of potential risk of harm (McMunigal 1998, 2001).

In that sense, all the executive directors are in a position of potential CoI. Actually, they are unlikely to aggressively monitor and evaluate the CEO, by virtue of their employment with the firm (Jensen and Meckling 1976; Rosenstein 1987).

For this reason, codes of best practice of corporate governance distinguish executive from nonexecutive directors. The latter may have or not have the attribute of independence. The nonindependent directors (or affiliated or 'grey' directors) have potential CoI (Weisbach 1988), since they have a family and/or professional relationships with the firm or firm management, so they maintain special relationships with the firm (Felo 2001). Although they are not employees, they may have been co-opted by management or the major shareholder through family and/or business ties. Independent directors are those with no current business ties to the firm on whose board they serve, nor employed in an occupation that might cause them to seek to ingratiate themselves to firm management. Consequently they may protect the interests of the principals more effectively than do other directors.

Sometimes the conflict with the primary interest of the firm is not evident for outside observers, since there is not a visible secondary interest (e.g. a familiar link or a related party transaction). One case is that of management entrenchment where managers can make investments that are more valuable under themselves than under alternative managers. 'By making manager-specific investments, managers can reduce the probability of being replaced, extract higher wages and larger perquisities from shareholders, and obtain more latitude in determining corporate strategy.' (Shleifer and Vishny 1989, p 123). Moreover managers could be oriented to maximize their own utility function that includes: power, prestige, firm size, etc., but, in doing so, do not maximize profit (Marris 1964).

The unobservable CoI is not disciplined by the CoI policy contained in the code of ethics, but through internal and external governance mechanisms (Shan 2013).

\section{From Conflict of Interest to Opportunistic Behaviour (Corruption)}

The literature on CoI is consensus that CoI is a situation, not a behaviour like the phenomenon of corruption that includes many forms of opportunistic behaviour. In corruption the secondary interest of the agent prevails on the primary interest of the principal, causing damage for the latter (Figure 1). Managers and directors are then corrupted (i.e. behave opportunistically) when they extract private benefits, damaging the firm and/or its stakeholders.

However, a CoI situation may be followed by a correct behaviour of the agent, if the primary interest prevails. Moreover, in case of a just apparent CoI, the interest of the agent may be perfectly aligned with that of the principal. 
Thus the main difference between $\mathrm{CoI}$ and corruption lies in the fact that the former is a situation of risk (sometimes even just apparent) while the latter is a harmful (or opportunistic) behaviour (McMunigal, 2001). In this sense corruption includes any form of abuse of power for private benefits: bribery, embezzlement, fraud, extortion, favouritism, and nepotism (Andvig et al. 2001; Tanzi 1998).

As stated by Carney (1998) corruption can be considered as the final stage of conflict of interest. Moreover, all cases of corruption include conflict of interest, whereas the opposite does not always hold good. Besides, corruption most often is a crime, conflict of interest incorporates a wide circle of various types of behaviours, the majority of which are not classified as crime (Carney).

Unlike the corruption, the CoI is characterised by a much wider scope of social and economic relations, most of which cannot be classified as a crime. For that reason CoI situations are not regulated by the law, but rather by codes of ethics or conduct (so-called soft law).

Indeed, the problem arises when the CoI situations are not properly managed, in view of the harmful effect that the degeneration of the $\mathrm{CoI}$ is able to produce. In particular, it refers to the phenomenon of corruption, which finds its antecedent in situations of unmanaged CoI. As stated by the Organization for Economic Cooperation and Development (OECD), "when CoI situations are not properly identified and managed, they can seriously endanger the integrity of organizations and result in corruption in the public sector and private sector alike' (OECD 2003, p. 13; see also ADB/OECD 2008, p. xiii; Transparency International 2009).

One of the major problems with $\mathrm{CoI}$ is that there is still a widely held view that $\mathrm{CoI}$ is equal to corruption (McMunigal 1998; Williams-Jones 2011). But CoI is not a crime. As a result of this negative connotation, the term CoI loses much of its utility, in practice, because of the risk of representing a barrier for activating the remedies to deal with it (Connolly 1996, p. 1555; Schneider 2010, p. 600). Even some scholars that analyse the code of ethics of corporations classify the CoI as a form of conduct against the firm (Carasco and Singh 2003; Kaptein 2010; Lefebvre and Singh 1992; Singh 2006).

\section{Conflict of Interest, Conflict of Commitment and Competing Interests}

Impairment of the judgment and corruption of the will (see Section 3) allow distinguishing CoI from conflict of commitment (Figure 1). Often people fail to understand the difference among them (Resnik 1998; Werhane and Doering 1997). A conflict of commitment or an appearance of conflict of commitment occurs when directors have different obligations that may conflict or place excessive demands on their time, effort, energy. This is the case of the 'busy' directors that sit on more than one board at the same time (Eisenhardt 1989; Fama and Jensen 1983; Fich and Shivdasani 2006). Therefore, the conflict of commitment does not necessarily undermine the judgment or the will (Resnik 1998), but it may reduce the time, the effort and the energy to serve each board. This is the reason why the codes of self-discipline of corporate governance for listed companies normally recommend directors to take into consideration this aspect when they accept the directorship.

'The directors shall accept the directorship when they deem that they can devote the necessary time to the diligent performance of their duties, also taking into account the commitment relating to their own work and professional activity, the number of offices held as director or statutory auditor in other companies listed on regulated markets (including foreign markets) in financial companies, banks, insurance companies or companies of a considerably large size' (Borsa Italiana 2015, p. 7).

Another important difference is that between CoI and competing interests (Foster 2003; Jenik and Julius 2009). Sometime they are used as synonymous. However, competing interests occur when the agent has different alternative solutions for achieving the primary interest of the principal (Jenik and Julius 2009, p. 16). The competing interests may lead to the cognitive conflict (Forbes and Milliken 1999), also commonly referred to as 'task' or 'constructive' conflict. It has been found to be beneficial for decision-making in top management teams (Amason 1996).

Thus, in competing interests the secondary interest of the agent is not present (Figure 1). However it cannot be excluded that also the cognitive conflict may be just apparent, hiding an actual CoI. It could be the case when directors seem to engage in a constructive conflict whereas they are just trying to protect their (sometime invisible) private or personal interests. 


\section{Methods}

This paper builds on explanatory single-case study by Yin (2014) based on a questionnaire administrated in 2013 to 18 directors who sit in the subsidiaries boards of a non-family Italian listed group. The questionnaire (see the Appendix) was submitted before these directors attended a course on CoI and corruption held by the author.

The draft questionnaire was pretested and validated by five independent experts to ensure appropriateness and none overlapping of question structure. One of the experts was the General Counsel of the listed business group, while the other academic experts organised the course.

Two months before that course the HR department of the parent company sent the author a list of the potential participants (62 directors of 32 subsidiaries) with the indication of their name and surname, the role in the board and the name of their subsidiaries. There were 12 CEOs, 6 chairmen, 3 CEOs and chairmen (i.e., in a situation of CEO duality), 41 non-executive directors among of them including 12 female directors. The subsidiaries are mainly wholly-owned by the parent company.

Five days before starting the course the HR department sent an email to the directors containing the link to the online questionnaire. The response rate was $29 \%$ (18 directors). Since the content of some questions (e.g. do you think of having found yourself in situations of conflict of interest in the past?), it was decided not to ask for respondents' demographic details (e.g. sex and age), and their role in the board (e.g. executive or non-executive) as all these elements could give the impression to the respondents of being identifiable, limiting further the response rate.

The first part of the questionnaire (Tables 1, 2 and 3) was designed aiming to understand: if the focus group supposes to know what the $\mathrm{CoI}$ is and if it is able to describe the differences between CoI and corruption.

After that, directors had to read the section (2 pages) of their code of ethics dedicated to the CoI policy. This code was issued by the holding company and is mandatory also for its subsidiaries. Thus all the directors of our focus group, despite belonging to different subsidiaries, must comply with the same code of ethics. The pre-reading creates homogeneity in the respondents in terms of knowledge of the CoI policy eliminating the risk that the different way to recognise the CoI depends on the fact that some may not know the content of that policy.

The Appendix does not contain the content of that policy in order to maintain the anonymity of the firm, given that it is listed and its code is easily downloadable from the corporate website and therefore findable through an internet search engine. However the definition of $\mathrm{CoI}$ is in line with the definition gave in Section 3.1, since all the three elements of the definition (primary interest, secondary interest and tendency to interfere) were present.

As emerged in the previous discussion the content of the three elements is not universally accepted. Thus, the incorporation of the three elements draws into question the validity of subsequently incorporating them in a questionnaire and drawing conclusions from the answers. However, our aim is to understand if a CoI definition is sufficient to identify and assess CoI situations (i.e. if directors give the same content to the three elements of the definition). In this regard the focus group is particular useful since the definition of CoI contained in the code of ethics is in line with our definition. In addition that code does not give any example of CoI that guides directors through the CoI identification.

For what concerns the primary interest, the group adopts the shareholder approach, since in the mission it is declared that the objective of the firm is to generate value for its shareholders.

The code of ethics does not cite the apparent as well as the potential CoI. However, the concept of apparent CoI is indirectly present in the Article 2391 of the Italian Civil Code. Thus, if directors fail to recognise the apparent CoI those rules will not be applied. In Italy this article is the most important in the regulation on directors' CoI, providing that: (i) if a director has a personal interest in a transaction (also if not necessarily conflicting but simply competing with the interest of the company), he/she must disclose it to the board of directors, and if he/she is also a managing director, he/she must abstain from carrying out the transaction deferring any relevant decision to the board of directors; (ii) if the company is managed by a sole director, he/she must disclose the interest to the general shareholders' meeting; (iii) the board of directors' resolution must properly explain the transaction's reasons and convenience for the company. 
Thus, pursuing the Italian Civil Code directors have to disclose also the apparent CoI. Indeed, even if they believe that their secondary interests are aligned with that of the firm they must disclose those interests. Indeed the apparent CoI exists when a secondary interest is present regardless of the fact that this interest actually interferes with the primary one. The compulsory disclosure requested by the Italian regulation allows the other board members to understand the reasons and the convenience for the company of such transaction. Moreover, since transactions with directors are considered as related party transactions they have to follow the Consob regulation, disclosing them in the annual report following the rules of International Accounting Standard 24 (Enriques 2009).

After directors read the content of the CoI policy, Table 4 asks several questions to understand their ability to recognise the CoI and its different typologies, as well as to distinguish that phenomenon from other types of conflict (i.e., conflict of commitment and competing interest). For each question directors had the possibility to come back to the content of the code and read the CoI definition. Those questions are then fundamental in our reasoning, since they aim to understand if the knowledge of a CoI definition is sufficient for the CoI identification.

The purpose of the design of the question contained in Table 5 was to understand what is the content directors give to the primary interest of the firm and thus if they are fully aware of the fact that the objective of their firm is to create value for shareholders. As discussed earlier, directors may give to that concept different content: interest of the shareholders, stakeholders or the firm it-self (Section 3). One situation may conflict with the interest of shareholder but can be in line with that of the stakeholders or the firm.

The first question of Table 6 asks the directors if the definition they read in their code is sufficient to identify the CoI situations represented in Table 4, while the second question asks the directors to give suggestions to improve the CoI policy in order to improve the CoI recognition.

The questions of Tables 1, 3 and 4 allow for a 'Yes', 'No' or 'I do not know' answer, while those of Tables 2, 5 and 6 are open-ended questions.

\section{$7 \quad$ Results and Findings}

\subsection{Conflict of Interest or Corruption?}

In Table 1 the answers to the question Q1 are extremely promising, since $94.4 \%$ of the focus group claims to be able to define what CoI is. This positive result may depend on the fact that the questionnaire was administered before starting a course on CoI and corruption, thus it could be expected that the answers may be affected by the so-called social desirability bias (King and Bruner 2000; Middleton and Jones 2000; Paulhus and Reid 1991). This effect leads the respondent wishes to provide the answer that is most 'socially acceptable' (say the 'right thing') rather than speak his/her true feelings. It may be expected that this effect would be particularly strong for directors given that one of their main roles is to monitor the managers' CoI.

The high percentage of 'Yes' to Q1 may also arise from the illusion of the respondents that they are able to define the CoI, thanks to their knowledge and skills. However, this positive illusion is questioned by the sample itself when asked if it is able to recognize CoI situations when they occur (Q4), since $77.8 \%$ says 'Yes' while $22.2 \%$ answers 'I do not know.' Consequently among those who said of being able to define the CoI there are some who claim not to be able to recognize it.

Particularly relevant are the answers to the question that asks the sample if it knows the difference between actual, apparent, and potential CoI (Q2). The percentage of those who claim to know this difference is just $22.2 \%$.

In order to understand what is the actual concept of CoI that directors really have it was not only asked if they know the difference between CoI and corruption, but also to define the two phenomena. Thus, Table 2 groups the most common open-ended responses. Some directors see the CoI as an opportunistic behaviour, an abuse of power (A1 and A2), rather than as a situation of risk, confirming our initial doubt.

This way of seeing the CoI is not just incorrect, but it could be a strong limit to the activation of remedies provided: if one believes that the CoI is an abuse of power, he/she hardly activates, for example, the remedy of disclosure (Section 4). 
In addition, from the open-ended responses of Table 2 it emerges that no one mentions the possibility that $\mathrm{CoI}$ could be also just apparent, since the respondents try to define the actual $\mathrm{CoI}$ or the potential one.

Questions of Table 3 ask which of the seven points listed (nepotism, cronyism, bribery, conflict of interest, embezzlement, favouritism, capture) are forms of corruption. Although only CoI is not corruption (Section 4), respondents seem to have different opinions. Only the bribery is regarded as corruption by all respondents. These answers may depend on the fact that in Italy only the crime of bribery is considered as corruption by the law, pursuant the Article 318 and 319 of the Italian Penal Code.

Hence, pursuant the Italian Penal Code, the boundaries of corruption are smaller than seen in the corruption definitions given by the literature.

\subsection{Usefulness of the Conflict of Interest Definition Provided by the Code of Ethics}

Tables 2 and 3 show that respondents do not give the same contents to the elements that characterise the definitions of $\mathrm{CoI}$ and corruption. The different answers may be resulted in two reasons: 1 ) directors do not know the content of the code of ethics; 2) directors know the content of that code but it is not sufficient to distinguish CoI from corruption.

For these reasons, after the questions of Tables 2 and 3 directors were asked to read the CoI policy containing in their code of ethics, in particular the CoI definition. After that reading the respondents had to say which of the situations listed in Table 4 falls within the CoI phenomenon.

Some situations represented in Table 4 are undoubtedly not CoI situations, while others may fall into the categories of actual, apparent or potential CoI. The aim of these questions is to understand if board members interpret in the same way the definition of CoI read in their code, answering to one of our research questions: Is the knowledge of the CoI definition sufficient in order to identify that phenomenon?

Moreover, the last column of Table 4 is added (so it was not present when the questionnaire was submitted) in order to provide evidence what are the CoI situations that directors have to disclose adopting the Article 2391 of the Italian Civil Code. As observed before, this article asks to disclose even the apparent CoI.

From the answers it is clear that even if directors use the same definition of CoI they recognise the phenomenon in different ways, evidencing that the definition is not sufficient.

\subsection{Primary Interest of the Principal in the Conflict of Interest Definition}

Table 5 contains the most significant answers to the open-ended questions that asked what might be the primary interest in the CoI definition. Some directors are shareholders oriented (A7) while others are stakeholders (A10) or firm (A1, A2, A4 and A5) oriented, or without a clear orientation (A3 and A6). As said earlier, the holding company clearly states in its mission that its objective is to create value for the shareholders.

One of the elements of the CoI definition is the primary interest that directors have the duty to achieve (Section 3.1). If the content of that element is not specified (i.e., what the interest of the firm should be) there is a risk that directors will have different opinions on this aspect. In particular, it may lead to recognise CoI in different ways and to have confusion when directors are faced with different solutions for achieving the primary interest (i.e., in case of competing interests).

\subsection{Suggestions to Improve the Conflict of Interest Policy}

In the last part of the questionnaire (Table 6) it was asked to the directors if the CoI definition contained in their code and read before answering to the questions of Table 4 had been useful in order to recognize the CoI situations. The possible answers ranged from 1, 'definitely No,' to 5, 'definitely Yes.' The average score was 3.78 .

Then directors were asked to give suggestions in order to improve their code for what concern the CoI recognition. One respondent says that the definition is 'clear but generic so it could be understood in a restrictive way' (A1). Another says that 'it should be added an annex explaining better the scope of the conflict of interest that is likely to be interpreted only in the financial aspects' (A2). These answers 
confirm that in order to recognise the CoI it is necessary to clarify the content of the three elements (primary interest, secondary interest, tendency to interfere) since individuals could interpret these elements in different ways. In this regard one answered that the CoI recognition 'just depends on my level of expertise on the subject' (A8).

Several directors suggest including examples in order to facilitate the recognition of the phenomenon (A4, A5 and A10). This is consistent with the scholars who found necessary to give numerous examples to better explain their CoI definition (Carson 1994; Davis 1993).

\section{Conclusion and Remarks}

Agency theory recognises a central role to the board members in monitoring the potential CoI. However, to the best of our knowledge, prior studies did not adequately investigate this monitoring role for what concern the ability to recognise specific actual, potential and apparent CoI situations.

The codes of ethics normally contain the CoI policy, however the term 'conflict of interest' is seldom defined. Moreover, even when defined, codes do not specify the content of the three elements of the definition (i.e., primary interest, secondary interest and tendency to interfere) with the risk that directors give to the three elements different meaning. The consequence is in that they share the same definition but the way they identify the CoI is different.

Our results confirm this risk and suggest that the definition of CoI is not sufficient to identify the phenomenon, also when that definition is deeply known. Therefore, it is not the knowledge of the code of ethics, at least as regards the management of $\mathrm{CoI}$ that allows individuals to adequately deal with that conflict. Consequently, the instruments normally suggested in order to disseminate the code (e.g. publication on the company website, distributing to the target stakeholders, sign statements of knowledge of the principles of the code) are not effective if the CoI policy only define the phenomenon.

These results have several implications for researchers, practitioners and regulators.

First, researchers on corporate governance should focus more attention on the CoI as an antecedent of opportunistic behaviour of insiders (managers and shareholders). The CoI policies should be added to the internal and external governance mechanisms that have as objective to deal, not with the specific CoI situations (actual, potential and apparent), but instead to the potential CoI that arises from the separation between ownership and control (Section 3.3). Chugh et al. (2005) point out that while individuals are able to recognise the CoI of others they may fail to recognise their own CoI. The results of our study show that it is not just a cognitive bias, since it may depend on an intrinsic difficulty in recognize the phenomenon of CoI. These considerations seem to be particularly useful for studies on board behaviour.

Second, regarding practitioners, it is recommended to improve the quality of the code of ethics in the section on CoI, through numerous examples that can facilitate the identification of the phenomenon, as suggested by the directors of our sample. The method of 'question-and-answer', contained in some codes of conduct and publications on the management of CoI intended for public employees (e.g. ADB/OECD 2008; OECD 2005) appears to be particularly useful in this regard.

Third, another indication is given to whom have dealt with the ethical codes for the board of directors. For instance, Schwartz et al. (2005) identify six core ethical values to be followed (honesty, integrity, loyalty, responsibility, fairness, citizenship). Commenting that of loyalty they say 'in order to be considered acting with loyalty, directors should avoid [...] engaging in potential or apparent conflict of interest transactions' (p. 91). It is suitable to clearly define what potential and apparent CoI are.

In Italy the clarification of the definition of apparent $\mathrm{CoI}$ is necessary because the legal concept of $\mathrm{CoI}$ is based on that type of conflict (Section 5.1). As seen, Article 2391 of the Civil Code calls for directors to report any interest they have in a certain task. The answers to the questionnaire have indicated that some of our respondents would not consider some situations within the apparent CoI, even when they are. It follows that Article 2391 may not be applied properly.

Fourth, it is also appropriate to provide specific ethics program on CoI that includes not only code of ethics or code of conduct but also ethics training and ethics officers. For what concern the ethics training, comparing opinions of trainees during the lesson is an extraordinary opportunity to bring out the importance of managing the CoI, included the apparent one. Giving a certain situation for some individuals finding themselves in $\mathrm{CoI}$ is not a problem while for others it is. The former could learn from 
the reaction of the latter the relevance that assumes the reliable of the judgement. Ethics trainings are an effective way to underline the necessity to be not only independent but also to appear independent.

Schwartz et al. (2005) observe that ethics courses specific to board members allow them to understand their ethical responsibilities, often challenged by situations of CoI. For what concern this last aspect, the most important task of a specific training course on CoI is to raise awareness among individuals with regard to situations of risk that may find themselves, questioning their natural illusion to be considered more moral, competent and deserving than others and, therefore, less attacked by CoI situations (Chug et al. 2005). Individuals, in fact, seem to have a psychological barrier to the recognition of CoI, so as to make it invisible even to themselves.

The ethics courses should also make people understand the gravity of other forms of corruption, such as nepotism, cronyism, which otherwise are likely to be underestimated.

Finally, it would be appropriate that code of ethics better defines what is meant by primary interest in the CoI definition. In fact, while for some it may be the interest of the company, for others such interest may coincide with that of the shareholder. In the latter case requested by the shareholder at odds with the interests of the company may be considered legitimate.

For the regulators, as occurred in the public sector - where numerous documents on how recognise and manage the CoI have been published (ADB/OECD 2008; ICAC/CMC 2004; OECD 2003, 2005) - it would be appropriate that organizations that issue the codes of self-discipline for corporate governance have the same attention. In particular, these codes might contain a clear definition of CoI as well as typical explanatory examples of the phenomenon.

\section{$9 \quad$ Limitations}

The main limitation of the paper is the number of respondents in the case study. Since only 18 responses were received, it is difficult to apply statistical methods to the results or to sub-analyse responses. For example, using cross tabulation or correlation analysis. Thus, this study should be followed by an econometric verification, so as to ensure the generalizability of the results.

Moreover, the actual questionnaire was in Italian so it is hard to tell to what extent concerns arise from the translation. Thus, if for example the same questions were asked to a sample of UK directors they may give different content to the terms as 'nepotism', 'cronyism' etc. However, it confirms that using these terms without specifying their content and making concrete examples, may limit the effectiveness of the code of conduct.

\section{References}

1. ADB/OECD (2008). Managing conflict of interest: Frameworks, tools, and instruments for preventing, detecting, and managing conflict of interest.

2. Amason, A. (1996). Distinguishing the effects of functional and dysfunctional conflict on strategic decision making: Resolving a paradox for top management teams. Academy of Management Journal, 39(1): 123-148.

3. Andvig, J. C., Fjeldstad, O. H., Amundsen, I., Sissener, T., \& Soreide, T. (2001). Corruption: A review of contemporary research. CMI Report R, 7 .

4. Argandoña, A. (2004). Conflicts of interest: The ethical viewpoint. Working Paper 552, Chair of Economics and Ethics, IESE Business School, University of Navarra.

5. Bardhan, P. (1997). Corruption and development: A review of issues. Journal of Economic Literature, 35(3): 1320-1346.

6. Baysinger, B., \& Hoskisson, R. E. (1990). The composition of boards of directors and strategic control: Effects on corporate strategy. Academy of Management review, 15(1): 72-87.

7. Benson, G. C. S. (1989). Codes of ethics. Journal of Business Ethics, 8(5): 305-319.

8. Berle, A. A., \& Means, G. C. (1932). The modern corporation and private property. MacMillan, New York.

9. Boatright, J. (1992). Conflict of interest: An agency analysis. In Norman Bowie and R. Edward Freeman (eds.) Ethics and Agency Theory: An Introduction. New York: Oxford University Press, 187-203.

10.Borden, S. L., \& Pritchard, M. S. (2001). Conflict of interest in journalism. In Michael Davis and Andrew Stark (eds.), Conflict of Interest in the Professions, New York: Oxford University Press. 
11.Borsa Italiana (2015), Corporate governance code, July 2015.

12.Brooks, L. J. (1989). Corporate codes of ethics. Journal of Business Ethics, 8(2-3): 117-129.

13.Carasco, E. F., \& Singh, J. B. (2003). The content and focus of the codes of ethics of the world's largest transnational corporations. Business and Society Review, 108(1): 71-94.

14.Carney, G. (1998). Conflict of interest: Legislators, ministers and public officials, Transparency International Working Paper.

15.Carson, T. L. (1994). Conflicts of Interest, Journal of Business Ethics, 13(5): 387-408.

16.Chugh, D., Bazerman, M. H., \& Banaji, M. R. (2005). Bounded ethicality as a psychological barrier to recognizing conflicts of interest, in Moore, D.A., Cain, D.M., Loewenstein, G. \& Bazerman, M.H., Conflicts of Interest, Cambridge University Press, Cambridge, UK, 74-95.

17.Claessens, S., Djankov, S., \& Lang, L. H. P. (2000). The separation of ownership and control in East Asian corporations. Journal of Financial Economics, 58(1): 81-112.

18.Connolly, C. K. (1996). Conflict of interest. Conflict of interest statement should be abolished, British Medical Journal, 313(7071): 1555-1556.

19. Cressey, D. R. and C. A. Moore (1983). Managerial values and corporate codes of ethics. California Management Review, 25(4): 53-77.

20.Davis, J. H., Schoorman, F. D., \& Donaldson, L. (1997), Toward a stewardship theory of management. Academy of Management Review, 22(1): 20-47.

21.Davis, M. (1982). Conflict of interest. Business \& Professional Ethics Journal, 1(3): 17-27.

22.Davis, M. (1993). Conflict of interest revisited. Business \& Professional Ethics Journal, 12(4): 21-41.

23.Davis, M., \& Stark, A. (2001). Conflict of interest in the professions. New York: Oxford University Press

24.Demsetz, H. and Lehn, K. (1985). The structure of corporate ownership: causes and consequences. Journal Denis, D.K., \& McConnell, J.J. (2003). International corporate governance. Journal of Financial and Quantitative, 38(1): $1-36$.

25.Di Carlo, E. (2013). How much is really known about the meaning of the term conflict of interest? International Journal of Public Administration, 36(12): 884--896.

26.Di Carlo, E. (2014). Related party transactions and separation between control and direction in business groups: the Italian case. Corporate Governance: The International Journal of Business in Society. 14(1): 58-85.

27.Di Carlo, E., \& Testarmata, S. (2011). Defining directors' conflict of interests in code of ethics. Corporate Board: Role, Duties \& Composition, 7(1): 125-139.

28.Di Carlo, E., \& Testarmata, S. (2012). Recognizing and managing conflict of interest: The case of Italian listed companies, DSI Essays Series, 20, McGraw-Hill.

29.Dunfee, T. W. (1999). Corporate governance in a market with morality. Law \& Contemporary Problems, 62(3): $129-158$.

30.Eisenhardt, K. M. (1989). Agency theory: An assessment and review. The Academy of Management Review, 14(1): $57-74$.

31.Enriques, L. (2009). Corporate governance reforms in Italy: What has been done and what is left to do. European Business Organization Law Review, 10(4): 477-513.

32.Fama, E. (1980). Agency problems and the theory of the firm. Journal of Political Economy, 88(2): 288-307.

33.Fama, E., \& Jensen, M. C. (1983). Separation of ownership and control. Journal of Law and Economics, 26(2): $301-325$.

34.Felo, A. J. (2001). Ethics programs, board involvement, and potential conflicts of interest in corporate governance. Journal of Business Ethics, 32(3): 205-218.

35.Fich, E., \& Shivdasani, A. (2006). Are busy boards effective monitors? The Journal of Finance, 61(2): 624-689.

36.Fields, M. A., \& Keys P. Y. (2003). The emergence of corporate governance from Wall St. to Main St.: Outside directors, board diversity, earnings management, and managerial incentives to bear risk, The Financial Review, $38(1), 1-24$.

37.Forbes, D.P. \& Milliken, F.J. (1999). Cognition and corporate governance: Understanding boards of directors as strategic decision-making groups. The Academy of Management Review, 24(3): 489-505.

38.Foster, R. S. (2003). Conflicts of interest: Recognition, disclosure, and management. Journal of the American College of Surgeons, 196(4): 505-517. 
39.Friedman, M. (1970), The social responsibility of business is to increase its profits, New York Times Magazine (September 13), 33: 122-126.

40.Friedman, P. J. (1992). The troublesome semantics of conflict of interest. Ethics \& behavior, 2(4): $245-251$.

41.Gaumnitz, B. R., \& Lere, J. C. (2002). Contents of codes of ethics of professional business organizations in the United States. Journal of Business Ethics, 35(1): 35-49.

42.Gillan, S. L. (2006). Recent developments in corporate governance: An overview. Journal of corporate finance, 12(3): 381-402.

43.Gordon, E., Henry, E. \& Palia D. (2004). Related party transactions and corporate governance. Corporate Governance Advances in Financial Economics, 9(1): 1-27.

44.Gordon, E., Henry, E., Louwers, T. \& Reed, B. (2007). Auditing related party transactions: A literature overview and research synthesis. Accounting Horizons, 21(1): 81-102.

45.Hermalin, B., \& Weisbach, M., (2003). Boards of directors as an endogenously determined institution: A survey of the economic literature. Economic Policy Review-Federal Reserve Bank of New York, 9(1): 7-26.

46.ICAC/CMC (2004). Managing conflicts of interest in the public sector: Guidelines, Independent Commission Against Corruption and the Crime and Misconduct Commission, 1-24.

47.Jenik, R., \& Julius, T. (2009). Resolving conflicts of interest in State-owned enterprises. International Social Science Journal, 57(s1): 11-20.

48.Jensen, M. C., \& Meckling, W. (1976). Theory of the firm: Managerial behavior, agency costs, and capital structure. Journal of Financial Economics, 3(4): 305-360.

49.Kaplan, S. N., \& Reishus, D. (1990). Outside directorships and corporate performance. Journal of Financial Economics, 27(2): 389-410.

50.Kaptein, M. (2004). Business codes of multinational firms: What do they say? Journal of Business Ethics, 50(1): 13-31.

51.Kaptein, M. (2010). The ethics of organizations: A longitudinal study of the US working population. Journal of Business Ethics, 92(4): 601-618.

52.Kaye, B. N. (1992). Codes of ethics in Australian business corporations. Journal of Business Ethics, 11(11): 857862.

53.King, M. F., \& Bruner, G. C. (2000). Social desirability bias: A neglected aspect of validity testing. Psychology \& Marketing, 17(2): 79-103.

54.Kohlbeck, M. \& Mayhew, B. (2010). Valuation of firms that disclose related party transactions. Journal of Accounting and Public Policy, 29(2): 115-137.

55.Lan, L. L. \& Heracleous L. (2010). Rethinking agency theory: The view from law. Academy of Management Review, 35(2), 294-314.

56.Lo, B., \& Field, M. J. (2009). Conflict of interest in medical research, education, and practice. Committee on Conflict of Interest in Medical Research, Education, and Practice - Institute of Medicine of the National Academies. Washington (DC): National Academies Press (US).

57.Mace, M. L. (1971). Directors: Myth and reality. Harvard Business School Press, Cambridge.

58.Marris, R. (1964). The economic theory of managerial capitalism. (Vol. 258), Macmillan, London.

59.McMunigal, K. C. (1998). Distinguishing risk from harm in conflict of interest. Business and Society Review, 100(101): 91-93.

60.McMunigal, K. C. (2001). Conflict of interest as risk analysis. In Michael Davis and Andrew Stark (eds.), Conflict of Interest in the Professions, New York: Oxford University Press.

61.Middleton, K. L., \& Jones, J. L. (2000). Social desirable response sets: The impact of country culture. Psychology \& Marketing, 17(2): 149-163.

62.Milgram, S. (1963), Behavioural study of obedience. Journal of Abnormal and Social Psychology, 67(4): 371-378. 63.Milgram, S. (1974), Obedience to authority. An experimental view. New York: Harper and Row.

64.Moore, D. A., \& Loewenstein, G. (2004). Self-interest, automaticity, and the psychology of conflict of interest. Social Justice Research, 17(2): 189-202.

65.Morck, R. (2008). Behavioral finance in corporate governance. Independent directors and non-executive chairs. Journal of Management and Governance, 12(2): 179-200.

66.Morck, R., \& Yeung, B. (2003). Agency problems in large family business groups. Entrepreneurship Theory and Practice, 27(4): 367-382. 
67.Nye, J. S. (1967). Corruption and political development: A cost-benefit analysis. American Political Science Review, 61(2): 417-427.

68. Organisation for Economic Co-operation and Development (OECD) (2005), Managing conflict of interest in the public sector: A Toolkit.

69. Organisation for Economic Co-operation and Development (OECD) (2003). Managing conflict of interest in the public service, OECD guidelines and country experiences, OECD Publishing, Paris, FR.

70.Orts, E. W. (2001). Conflict of interest on corporate boards. In Michael Davis and Andrew Stark (eds.), Conflict of Interest in the Professions, New York: Oxford University Press.

71.Osterloh, M., \& Frey, B. S. (2000). Motivation, knowledge transfer, and organizational forms. Organization Science, 11(5): 538-550.

72.Paulhus, D. L., \& Reid, D. B. (1991). Enhancement and denial in social desirability bias. Journal of Personal and Social Psychology, 77(5): 307-317.

73.Resnik, D. (1998). Conflicts of interest in science. Perspectives on Science, 6(4): 381-408.

74.Rose, J. M. (2007). Corporate directors and social responsibility: Ethics versus shareholder value. Journal of Business Ethics, 73(3): 319-331.

75.Schneider, N. (2010). Awareness and management of conflicts of interest. Journal of Public Health, 18(6): 597600 .

76.Schwartz, M. S. (2004). Effective corporate codes of ethics: Perceptions of code users. Journal of Business Ethics, 55(4): 321-341.

77.Schwartz, M. S. (2005). Universal moral values for corporate codes of ethics. Journal of Business Ethics, 59(1-2): $27-44$.

78.Schwartz, M. S., Dunfee, T. W, \& Kline, M. J. (2005). Tone at the top: An ethics code for directors? Journal of Business Ethics, 58(1-3): 79-100.

79.Shan, Y. G. (2013). Can internal governance mechanisms prevent asset appropriation? Examination of type I tunneling in China. Corporate Governance: An International Review, 21(3): 225-241.

80.Shleifer, A. and Vishny, R. W. (1989). Management entrenchment: The case of manager-specific investments. Journal of Financial Economics, 25(1): 123-139.

81.Shleifer, A., \& Vishny, R. (1997). A survey of corporate governance. Journal of Finance, 52(2): 737-783.

82.Sims, R. R., \& Brinkmann, J. (2003). Enron Ethics (Or: Culture Matters More than Codes), Journal of Business Ethics, 45(3): 243-256.

83.Singh, J. (2006). A comparison of the contents of the codes of ethics of Canada's largest corporations in 1992 and 2003. Journal of Business Ethics, 64(1): 17-29.

84.Tanzi, V. (1998). Corruption around the world: causes, consequences, scope and cures. International Monetary Fund Staff Papers, 45(4): 559-594.

85.Thagard, P. (2007). The moral psychology of conflicts of interest: Insights from affective neuroscience. Journal of Applied Philosophy, 24(4): 367-380.

86.Thompson, D. F. (2009). The challenge of conflict of interest in medicine. German Journal for Evidence and Quality in Health Care, 103(3): 136-140.

87. Transparency International (2009). The anti-corruption plain language guide.

88.Weber, J. A. (2007). Business ethics training: Insights from learning theory, Journal of Business Ethics, 70(1): $61-85$.

89. Weisbach, M. (1988). Outside directors and CEO turnover. Journal of Financial Economics, 20: 431-460.

90.Werhane, P., \& Doering, J. (1997). Conflicts of interest and conflicts of commitment. In D. Elliott and J. E. Stern, eds. Research Ethics: A Reader. Hanover, N. H.: University Press of New England, 169-170.

91.White, B. J., \& Montgomery, B. R. (1980). Corporate Codes of Conduct. California Management Review, 23(2): $80-87$.

92.Winch, S. P. (2003). Conflict of Interest. In D. H. Johnston (eds.) Encyclopedia of International Media and Communications. Amsterdam: Elsevier, 325-331.

93.Yin, R. K. (2014). Case Study Research: Design and Methods, Thousand Oaks. California, Sage Publications.

94.Young, M. N., Peng, M. W., Ahlstrom, D., Bruton, G. D. \& Jiang Y. (2008). Corporate governance in emerging economies: A review of the principal-principal perspective. Journal of Management Studies, 45(1): 196-220. 


\section{Appendix}

\section{Cover sheet}

The purpose of this questionnaire is to understand how well you know the phenomena of conflict of interest and corruption.

Reply with serenity and sincerity, with the certainty of absolute anonymity.

I would be grateful not to change the answers, once given, not to skew the results of the analysis.

Table 1. Conflict of interest and corruption

\begin{tabular}{l|c|c|c}
\hline & Yes & No & I do not know \\
\hline $\boldsymbol{Q 1 .}$ Are you able to define what conflict of interest is? & $94.4 \%$ & $00.0 \%$ & $5.6 \%$ \\
\hline $\begin{array}{l}\boldsymbol{Q} \text { 2. Do you know the difference between actual, apparent and potential } \\
\text { conflict of interest? }\end{array}$ & $22.2 \%$ & $61.1 \%$ & $16.7 \%$ \\
\hline $\begin{array}{l}\boldsymbol{Q} \text { 3. Have you ever heard about the difference between the actual, } \\
\text { apparent and potential conflict of interest? }\end{array}$ & $22.2 \%$ & $72.2 \%$ & $5.6 \%$ \\
\hline $\boldsymbol{Q 4}$. Are you able to recognize a conflict of interest when it occurs? & $77.8 \%$ & $00.0 \%$ & $22.2 \%$ \\
\hline $\begin{array}{l}\boldsymbol{Q} \text { 5. In the past, do you think of having found yourself in situations of } \\
\text { conflict of interest (also not in this company)? }\end{array}$ & $50.0 \%$ & $50.0 \%$ & $00.0 \%$ \\
\hline $\begin{array}{l}\boldsymbol{Q} \text { 6. Are you able to describe the difference between conflict of interest } \\
\text { and corruption? }\end{array}$ & $88.9 \%$ & $00.0 \%$ & $11.1 \%$ \\
\hline
\end{tabular}

Table 2. Differences between conflict of interest and corruption

Open-ended responses given to the following question: 'Can you describe briefly what is, in your opinion, the difference between conflict of interest and corruption?'

A1. Conflict of interest: decisions for the benefit of the personal sphere of who decides; Corruption: decision taken to have a private financial gain

A2. Conflict of interest occurs when, by virtue of a liability, you are taking behaviors that are not impartial. Corruption is a fraudulent behavior to reach a goal

A3. The conflict of interest is a situation in which personal interest may conflict with business and professional interests. Corruption is the implementation of the conflict itself

A4. The conflict of interest is a situation of potential conflict between the role of an individual and the individual's private interests that may conflict with the decisions to be taken. Corruption. Favours, in the face of dation of money and other benefits

A5. The conflict of interest is when I have to decide and I have a personal interest not in line with the Company's interests; Corruption is when I give something to another in order to obtain a contract or to influence a decision

Table 3. Forms of corruption

\begin{tabular}{l|c|c|c}
\hline Which of the following are forms of corruption? & Yes & No & I do not know \\
\hline 1. Nepotism & $27.8 \%$ & $44.4 \%$ & $27.8 \%$ \\
\hline 2. Cronyism & $55.6 \%$ & $16.7 \%$ & $27.8 \%$ \\
\hline 3. Bribery & $100.0 \%$ & $00.0 \%$ & $00.0 \%$ \\
\hline 4. Conflict of interest & $11.1 \%$ & $72.2 \%$ & $16.7 \%$ \\
\hline 5. Embezzlement & $66.7 \%$ & $33.3 \%$ & $00.0 \%$ \\
\hline 6. Favouritism & $44.4 \%$ & $27.8 \%$ & $27.8 \%$ \\
\hline 7. Capture & $11.1 \%$ & $00.0 \%$ & $88.9 \%$ \\
\hline
\end{tabular}


Below the conflict of interest policy extracted by your Code of Ethics. Read it carefully before answering the following questions.

[Omitted to Maintain the Anonimity of the Company]

Table 4. Using the definition of conflict of interest above, are you able to identify which of the following situations are in conflict of interest?

\begin{tabular}{|c|c|c|c|c|}
\hline & Yes & No & $\begin{array}{l}\text { I do } \\
\text { not } \\
\text { know }\end{array}$ & $\begin{array}{l}\text { Adopting } \\
\text { the art. 2391 } \\
\text { of the Italian } \\
\text { Civil Code } \\
\end{array}$ \\
\hline $\begin{array}{l}\text { Q1. I am in charge of personnel (but not the owner) of a } \\
\text { private company and I have to decide if hiring one of my close } \\
\text { family member who, however, is the most competent person in } \\
\text { the labour market to play a certain role }\end{array}$ & $83.3 \%$ & $16.7 \%$ & $00.0 \%$ & Yes \\
\hline $\begin{array}{l}\text { Q1.1. In Q1, if I were also the owner of the company with } \\
100 \% \text { of the shares }\end{array}$ & $38.9 \%$ & $61.1 \%$ & $00.0 \%$ & Yes \\
\hline $\begin{array}{l}\text { Q1.2. In Q1, if I were also the owner of the company with } \\
51 \% \text { of the shares }\end{array}$ & $77.8 \%$ & $22.2 \%$ & $00.0 \%$ & Yes \\
\hline Q1.3. In Q1, if I were in a public administration & $83.3 \%$ & $11.1 \%$ & $5.6 \%$ & Yes \\
\hline $\begin{array}{l}\text { Q1.4. In Q1, if my family member were not a competent } \\
\text { person }\end{array}$ & $100.0 \%$ & $00.0 \%$ & $00.0 \%$ & Yes \\
\hline $\begin{array}{l}\text { Q1.5. In Q1.4, if I were also the owner of the company with } \\
100 \% \text { of the shares }\end{array}$ & $66.7 \%$ & $33.3 \%$ & $00.0 \%$ & Yes \\
\hline $\begin{array}{l}\text { Q1.6. In Q1.4, if I were also the owner of the company with } \\
51 \% \text { of the shares }\end{array}$ & $94.4 \%$ & $5.6 \%$ & $00.0 \%$ & Yes \\
\hline $\begin{array}{l}\text { Q2. I am a manager and I have to choose between two } \\
\text { alternative investments (one excludes the other). The former } \\
\text { generates a return for shareholders higher than the second. } \\
\text { However, from environmental sustainability point of view, the } \\
\text { second investment is preferable to the first. }\end{array}$ & $16.7 \%$ & $66.7 \%$ & $16.7 \%$ & No \\
\hline $\begin{array}{l}\text { Q3. I am a manager and I carry out parallel activities forcing } \\
\text { me to fail to commitments with my company }\end{array}$ & $94.4 \%$ & $00.0 \%$ & $5.6 \%$ & No \\
\hline \multicolumn{5}{|c|}{ Q4. I am a member of the board and I have to express a judgment on the following operations (da 4.1 a 4.3 ): } \\
\hline $\begin{array}{l}\text { Q4.1. hire as manager a member of my family, but I am a } \\
\text { person with sound moral principles and therefore I do not get } \\
\text { influenced. The family tie does absolutely not affect the choice. }\end{array}$ & $66.7 \%$ & $22.2 \%$ & $11.1 \%$ & Yes \\
\hline $\begin{array}{l}\text { Q4.2. purchase legal services from the agency of a board } \\
\text { member. Given that such director is a graduate in my own } \\
\text { university is my age and supporting my own team, I feel a } \\
\text { strong desire to favour him }\end{array}$ & $77.8 \%$ & $22.2 \%$ & $00.0 \%$ & No \\
\hline $\begin{array}{l}\text { Q4.3. hire as manager a family member of the majority } \\
\text { shareholder to whom I owe my appointment as board member. }\end{array}$ & $83.3 \%$ & $16.7 \%$ & $00.0 \%$ & No \\
\hline $\begin{array}{l}\text { Q5. I am the purchasing manager of my company, and now } \\
\text { my wife (or husband) is hired by one of my suppliers }\end{array}$ & $88.9 \%$ & $00.0 \%$ & $11.1 \%$ & Yes \\
\hline $\begin{array}{l}\text { Q6. I am the purchasing manager of my company, and I must } \\
\text { decide whether purchase insurance services from the company } \\
\text { where my wife is employed }\end{array}$ & $72.2 \%$ & $16.7 \%$ & $11.1 \%$ & Yes \\
\hline
\end{tabular}


Table 5. Interest of the firm in the conflict of interest definition

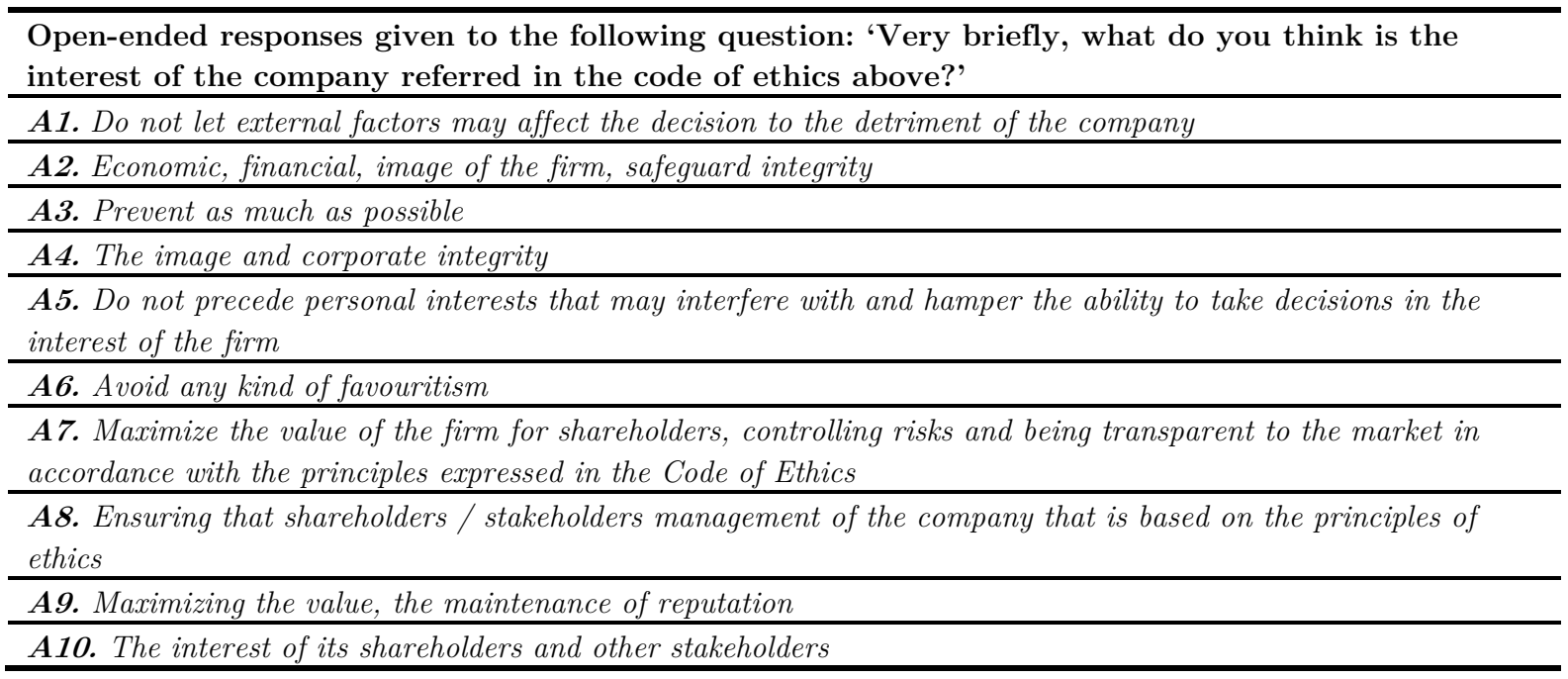

Table 6. How to improve the conflict of interest policy

Do you think that the definition of conflict of interest has been sufficient to detect situations of conflict of interest? (Definitely $\mathrm{No}=1$; Definitely $\mathrm{Yes}=5$ ): Average 3.78

Motivate the previous answer, and if the score is less than or equal to 4 , what do you propose to improve the conflict of interest recognition?

A.1. It is clear but generic so it could be understood in a restrictive way.

A.2. It should be added an annex explaining better the scope of the conflict of interest that is likely to be interpreted only in the financial aspects

A.3. Everything is perfectible

A.4. Explain a number of examples / situations more difficult to interpret for the avoidance of doubt

A.5. Prepare and distribute to the parties concerned examples of application of the rule that help to identify the conflict of interest

A.6. Generic - to deepen my knowledge about the higher risk situations (eg, purchases, collaborations)

A.7. The text is clear but I think the key lies in the ability of the individual to internalize in a profound way the concept of ethics

A.8. It just depends on my level of expertise on the subject, so I cannot respond well.

A.9. Information campaign

A.10. Enclose the text clear examples 